\title{
Classical Heritage and European Identities
}

The Imagined Geographies of Danish Classicism

\section{Lærke Maria Andersen Funder, Troels Myrup Kristensen and Vinnie Nørskov}

First Published 2019

\section{Classical heritage and European identities}

Introducing the Danish case

(CC BY-NC-ND 4.0)

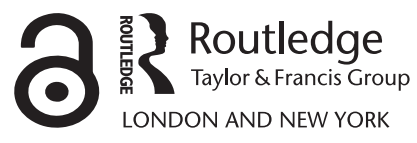




\section{Classical heritage and European identities}

\section{Introducing the Danish case}

A large sign, carrying the blue and yellow insignia of the European Union (EU), greets visitors to the Athenian Acropolis, announcing in capital letters in Greek and English that "Europe starts here!" (Figure 1.1). The accompanying text spells out the long-term significance of the site for European identity (in the singular): "The Acropolis and its surrounding Archaeological Sites, the heart of Ancient Athens, is the place where the most essential aspects of the European identity emerged: Democracy, Philosophy, Theatre, Sciences, Arts." The sign is a material manifestation of the fact that ancient Athens as a whole is the recipient of the European Heritage Label, instituted by the EU in 2013 and given to sites that are identified as having an intrinsic, symbolic value to European history.

The Acropolis sign, the heritage label that it represents, as well as the evocation of similar themes in the House of European History in Brussels are potent reminders of the continuous investment in classical (Greek and Roman) antiquity as a seemingly positive and harmonious foundation story in European history, in contrast to the dark and antagonistic heritage attributed to, for example, the Second World War or the Cold War. Official visits to Athens by Emmanuel Macron and Barack Obama in 2016 and 2017 respectively further demonstrate the level of this symbolic and political investment in Greece as the place where European and, by seemingly straightforward extension, Western civilisation began - a story that is also perpetuated in academic work (for example Meier 2011). In their public speeches in Athens, both the French and the US presidents construed Greece as the birthplace of Western democracy. Macron even linked the glory of Greece's past with the future of Europe - a statement that carried both symbolic potency and urgency when seen in light of the many political crises that currently face the continent. ${ }^{2}$

The European (and, more broadly, Western) use of classical antiquity as a role model that is evident in both the Acropolis sign and the presidents' 


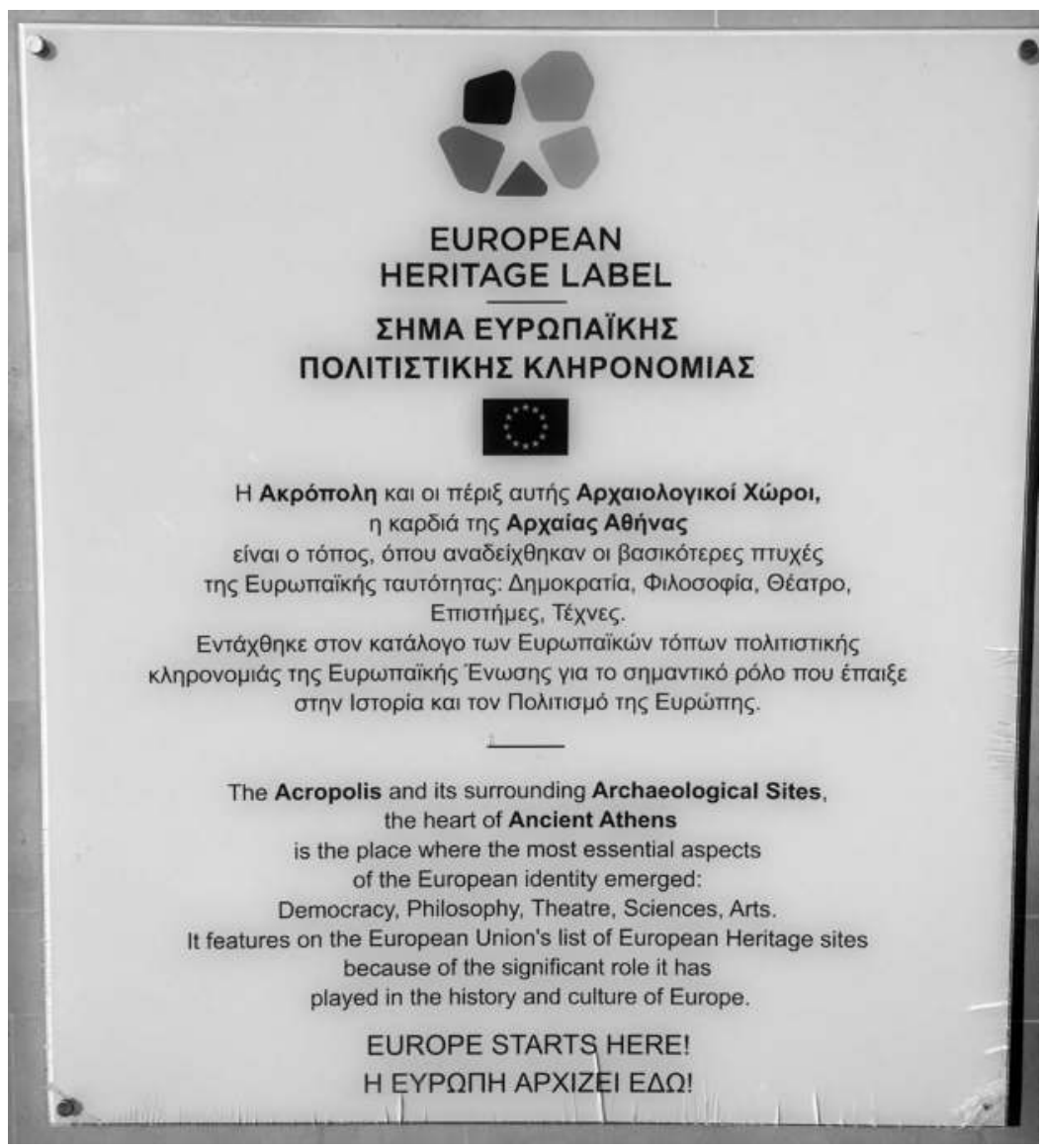

Figure 1.1 Europe starts here! European Heritage Label at the entrance to the South Slope of the Athenian Acropolis, January 2018

Source: Photo courtesy of Troels Myrup Kristensen

Athenian speeches has origins going back to the Renaissance, when Italian humanists turned the rediscovery of ancient texts into a new culture and aesthetics (Baker 2015). Classicism, defined as applying models from classical antiquity in a prescriptive sense, developed from the Renaissance and especially over the course of the "long" nineteenth century from the French Revolution to the First World War into one of the most influential discourses through which notions of civilisation, nationhood, citizenship and identity were mirrored, constructed and prescribed. (Marchand 1996; Fögen and 
Warren 2016). In this period, European art, architecture, science, education and civic institutions consciously evoked the diverse heritages of Greek and Roman antiquity, developing a shared, symbolic language that connected the contemporary ambitions of individual nations and their institutions with the seemingly eternal glory and grandeur of the classical past (Silk et al. 2014; see Raabyemagle and Smidt 1998 for Danish examples). Models from classical antiquity - not least the ideology of Roman imperialism - became powerful instruments in the administration of European colonies around the world, legitimising practices such as slavery and racism (Goff 2005; Bradley 2010). During the first part of the twentieth century, the appropriation of classical antiquity for political means experienced yet another dark chapter, when the Fascists in Italy and the Nazis in Germany actively used classicising models in their propaganda (Nelis 2008; Arthurs 2012). Today, contemporary uses of classical antiquity range from the highly nationalist and racist agendas of right-wing parties such as Greece's Golden Dawn (Hamilakis 2016) to the universalising and positive image of the "birthplace of Europe" as evoked by Macron, as well as the award of the European Heritage Label to the monuments of ancient Athens at large.

This book examines how different agents and institutions within the Danish nation state have situated themselves within this complex landscape of competing appropriations of classical antiquity from the eighteenth century to the present day. In particular, it focuses on the use of classical heritages to construct both European and national identities (in the plural) and especially on how Danes in this period have engaged with a sense of European commonality through their engagements with the classical past. Although Denmark was never geographically part of the ancient Greek or Roman world, it has a long tradition of employing classicism to provide models for contemporary society, citizenship culture and science. A precursor of this tradition goes back to the Edda of the thirteenth century, when the Icelandic poet and historian Snorri Sturluson (1179-1241) let the Norse gods be descendants of the Trojan kings (Stavnem 2011). Classicism intensified during the Renaissance and became firmly embedded in Danish national institutions from the late eighteenth century onwards. Its continued vitality is contingent on the dynamic adaptation of classical heritages, material as well as immaterial, into Danish cultural identities.

Like other Northern European countries situated beyond the Roman limes and even further away from the pinnacles of Mount Olympus, Denmark developed both a narrative and a habitus that linked itself with classical antiquity, not through some sense of spatial continuity but through its incorporation into an idea of a common European heritage in which Denmark was believed to have an important share. Even if this discourse is centuries old and has never been hegemonic, it continues to shape important aspects of how the 
Danish nation defines itself. For instance, as we were writing this book, Mette Bock, the current Danish Minister of Culture and Member of Parliament for the Liberal Alliance, declared in an interview with a major newspaper that Danes would benefit from reading more Plato (Kassebeer 2017).

Through its location between continental Europe and the other Nordic countries, Denmark can be seen as a liminal or transitional area that often finds itself split between European and Nordic identities, something that has been evident in Danish politics in the past 50 years, not least in the country's ambiguous relationship with the EU (Miles and Wivel 2014; Hansen 2001, 2002). Denmark joined the EU (then the European Economic Community) in 1973, but on several occasions the country has rejected closer integration during referendums on the Maastricht Treaty in 1992, the European Monetary Union in 2000 and the so-called opt-outs in 2015. Furthermore, Denmark's classical heritage (and by implication, its identity as a European country) has historically competed with Nordic or even entirely national notions of identity, often in complex ways. ${ }^{3}$ For example, the right-wing nationalist and EU-sceptic Danish People's Party (Dansk Folkeparti) has on several occasions defended the place of the classics in Danish education by referring to their role in introducing students more broadly to history and culture, in spite of their otherwise rigid emphasis on what is perceived as specifically Danish heritage, such as the Viking monuments at Jelling (Niklasson and Hølleland 2018).

The central argument of this book is that the continual employment and appropriation of classical heritages in the Danish context constitutes a significant case of an imagined geography, which places the birth of European identity within the culture-historical imaginary of classical antiquity. Through three case studies, we intend to demonstrate how this imagined geography has been embedded and even naturalised in distinctive ways within the educational and heritage sectors. The case studies explore three significant and interrelated arenas in which classical heritages are used to construct particular identities and to shape Danes as European citizens. In the following sections, we lay out the book's theoretical framework, especially the intersection between classical reception studies and the emerging field of critical heritage studies, as well as the concept of imagined geography and how it is applied in our analysis of the relationship between identity, nationalism and classicism in Denmark. Finally, we turn to the empirical and methodological background for the three case studies.

\section{Classicism as critical heritage}

The book implements a critical historiographical perspective in line with recent work in classical reception that has stressed the dialectical relationship between past, present and future (Settis 2006; Martindale 2006; 
Hardwick and Stray 2008; Prettejohn 2012; Hanink 2017). It thus contributes to a large and growing body of scholarship at the intersection between Classical Studies (in which the study of postantique appropriations of classical antiquity has become increasingly common) and Heritage Studies (which among other things has explored more generally how people use the past to construct particular identities to shape present and future: Smith 2006; Harrison 2013; Macdonald 2013). This section provides a brief overview of some of the key developments in these fields in order to contextualise the book's arguments within their broader theoretical setting.

The study of postantique uses of classical heritage is often carried out under the umbrella of classical reception, implying a passive process of transmission from classical antiquity to more recent periods. There is indeed a long tradition of undertaking studies on the rediscovery of classical antiquity by artists and architects, including in Danish scholarship, where, for example, the grand tour travels of Danish painters and sculptors have been traced in great detail (prominent examples include Nielsen 1990; Bendtsen 1993; Dietz 1999; Christiansen 2000; Fejfer et al. 2003; Nørskov 2008; Nielsen and Rathje 2010). Traditional studies have also investigated collecting practices and the formation of museum collections that forged a material link to the classical past that was not recoverable from the Danish soil (for instance, Krogh and Guldager Bilde 1997; Nørskov 2002; Rasmussen et al. 2000; Moltesen 2012). In the most recent wave of classical reception studies (Martindale 2007, 2013; Hardwick 2003), the scope of the discipline in terms of its material and approach has been substantially broadened. Charles Martindale has highlighted how reception denotes a dynamic and reciprocal process of understanding that "illuminates antiquity as much as modernity" (Martindale 2013, 171). Classical antiquity constantly mutates as we engage with it from our own historical and contextual place in time. In the continually developing process of reception, new and unexplored aspects of antiquity come into focus through the changing contexts of interpretation (Martindale 2013, 181). This more nuanced, critical approach to reception studies is increasingly incorporated into the study of classics. It has transformed the discipline from a positivistic and normative tradition that essentially confirms classical antiquity as a "world that had nurtured civilisations and whose achievements eclipsed anything accomplished by Western Europe until the Renaissance" (Vasunia and Stephens 2010,3) towards a reflective, poststructural and hermeneutically informed practice that is conscious of its own temporal and cultural situatedness and influence.

Embedded in the above understanding of the reception and use of classical heritage is a notion of time as cyclical. In Salvatore Settis's thoughtful and in-depth discussion of the complexity of the "classical" as concept and 
phenomenon (2006), he presents its many meanings and uses as well as underlining cultural preconditions. The concept of classicism as we understand it as synonymous with Greek and Roman culture was not established before the early nineteenth century, but it builds on a conceptualisation of memory and the past that is based on a dichotomy between ancient and modern that developed in the early Renaissance (Settis 2006, 56-99). The idea of rebirth that underpins the idea of classicism - expressed literally in the use of the term Renaissance to denote a historical period - implies death and then recovery, building on an organic idea of life as a model of historical thinking with a rhythmical process of deaths and rebirths. The word classical also implies ideas about values and ideals defining, on the one hand, "first class" and, on the other, a specific aesthetic that is harmonious, balanced and moderate (Settis 2006, 64-65). In this is implied an elitist, Western set of values that has in recent years been questioned. In reception studies, this has been defined as a "democratic turn," drawing inspiration from postcolonial and feminist theory. The democratic turn entails three perspectives that have been fundamental to current reception studies (Hardwick and Stray 2008, 3). Firstly, it questions the notion of the inherent superiority and normative power of classical culture in the West (Joshel et al. 2001; Cuno 2008; Bilsel 2012); secondly, it investigates and challenges the traditional conceptualisation of classics as belonging exclusively to the elite; and, thirdly, it turns the attention towards how classics has been received and appropriated in much wider social contexts, including outside Europe (Hall 2008; McElduff 2006; Paul 2010, 2013). In this book, we use this scholarship to nuance and contextualise the sometimes narrow and onedimensional Danish discussions of the value of classical heritage.

We also draw on insights from the emerging field of critical heritage studies in order to provide a broader view of classical antiquity as heritage. Sharon Macdonald defines heritage as places that can be visited; and classical heritage sites are traditionally perceived as places around the Mediterranean, (Macdonald 2013, 23). However, through imagined geography, this concept can be extended to a cognitive and imaginative sphere, as will be discussed below. The concept of critical heritage underscores not only its material aspects but also a critical approach to the inherent valuation that is at the core of sustaining something as heritage (Macdonald 2013, 18). The act of valuating aspects of the past, imbuing them with certain qualities, discursively establishes them as heritage. While the term heritage inherently comprises a central material aspect, the discursive operations inherent in selecting, preserving and perpetuating certain aspects of the past imbue it with an intangible aspect as well, as it becomes a way of understanding the world (Macdonald 2013, 18; Smith 2006, 43). These discursive operations are often implemented in the context of cultural and political institutions such as museums, academia, 
and the educational sector. Once something is established as "heritage," it is open to a constant dialectic between cultural and political confirmation and contestation (Smith 2006, 82). This is due to the nature of heritage as always belonging to a specific location and group of people (Macdonald 2013; Smith 2006, 3). Heritage can "turn the past from something that is simply there, or has merely happened, into an arena from which selections can be made and values derived . . turning the past into The Past" (Macdonald 2013, 18). In this view, heritage is a production of "The Past" in a given present (Harrison 2013, 32). Such normative views of an authorised heritage discourse have been very influential in the naturalisation of classical heritage in Denmark, as we will see in our case studies, and we will use scholarship from critical heritage studies to interpret the different ways in which different agents - both institutions and individuals - have shaped discourses of classicism in the Danish context.

\section{Imagined geography}

In order to grasp the role of classical heritage for identity building in an non-classical country, we have implemented the concept of imagined geography as an analytical tool. The concept provides a framework in which to read and interpret various uses and definitions of classical antiquity observed both in the Danish educational system and more broadly in the cultural heritage sector. We begin with a discussion of the concept of imagined geography, building on work by cultural studies scholar Edward Said and political scientist Benedict Anderson, and we discuss how it can be identified in particular key discourses that relate to classical heritage.

Imaginative geography - a close variant of the term - is used on several occasions in Said's highly influential Orientalism (Said 1978), although Said refrains from defining the concept explicitly. Said uses "imaginative geography" to refer to a particular way of ascribing meaning to geography on the basis of cultural tropes and in terms of binary oppositions, for example the loaded antithesis of East and West. Such tropes contain numerous layers of ideological baggage and constitute ways of naturalising a particular world view based on factoids (Said 1978, 71). Through imaginative geography, European scholars and artists have for centuries described the Near East as undeveloped and eternally Other. Orientalism is an exploration of what Said calls the "essential motifs of European imaginative geography" (Said 1978, 57). He traces such motifs in a range of different contexts that in effect constitute a highly toxic form of geographical determinism, which has important implications in the present. Said's work has been criticised for its focus on textual constructions of Orientalism, but it serves as a starting point for this discussion of the relationship between power and knowledge. 


\section{Classical heritage and European identities}

In Imagined Communities, Benedict Anderson's equally influential study of the origins of nationalism in the late eighteenth century, the nation is characterised as "an imagined political community" (Anderson 2016, 6; on its influence on Danish historiography, see Mentz 2004). Anderson continues: "It is imagined because the members of even the smallest nation will never know most of their fellow-members, meet them, or even hear of them, yet in the minds of each lives the image of their communion" (Anderson 2016,6). The communities of the nation state are thus bound together through shared narratives, images and, indeed, myths. One particularly useful aspect of Anderson's work in this context is the power with which the act of "imagining" is imbued: It is seemingly able to justify colossal sacrifices, notably in the service of state-sponsored violence. Although Anderson did not write his work from a postmodernist perspective, a pertinent influence of his concept in later work has been the study of the nation as a set of discourses that can be deconstructed (Smith 1998, 142). Anderson has been rightly criticised for paying little attention to materialisations of the imagined community, for example, those monuments that tie the nation together. As we shall see especially in chapters 3 and 4, the material aspects of imagined geography are indeed fundamental.

Imagined geography, as used here, refers to the creative ability of a given nation - as well as subgroups and individuals within that nation - to construct geography-driven discourses of identity. This sense of imagined geography acknowledges that there are always omissions and interruptions in the way that history is written and the way that identity is forged. An imagined geography can be based on "here" - that is, a place-based imagining of identity - as in the case of the Athenian Acropolis, which is fundamental in representations of the modern Greek nation and which remains one of the country's most important "theatres of memory" (Yalouri 2001; Hamilakis 2007, 85-98). At the same time, through a whole range of imagined geographies constructed on European essentialising tropes such as the "West" and "the birthplace of democracy" (as we already observed in relation to Figure 1.1), the Acropolis is claimed as European or even world heritage, as recently exploited by Macron and Obama during their visits. This example thus shows how the imagined geographies of a place connect several different scales of heritage, from the local to the global. Imagined geography thus becomes particularly layered when it operates with a "there" by transferring claims of a particular place or memory to somewhere else, as in the case of the Bavarian Walhalla, which was built as a copy of the Parthenon in Athens (even if its name evokes Norse mythology) and served as a hall of memory for the first Bavarian, then German state and its heroes. In the same way, collections of classical antiquities may be understood as representative of this imagined geography. The case of the Parthenon marbles - which were moved from the Athenian Acropolis by 
Lord Elgin to Britain, where they have been displayed in the British Museum in London since 1817 - is perhaps the best-known example of classical works claimed as world heritage, but every collection of classical antiquities partakes in this process of appropriation that reconfigures a particular country's place in the world. The prominent position in the Danish National Museum given to two small heads belonging to the Parthenon's metopes that were bought by Captain Moritz Hartmann in the streets of Athens in 1687 constitutes a powerful Danish example of how classical antiquities may participate in discourses of imagined geography within museum spaces (Figure 1.2).

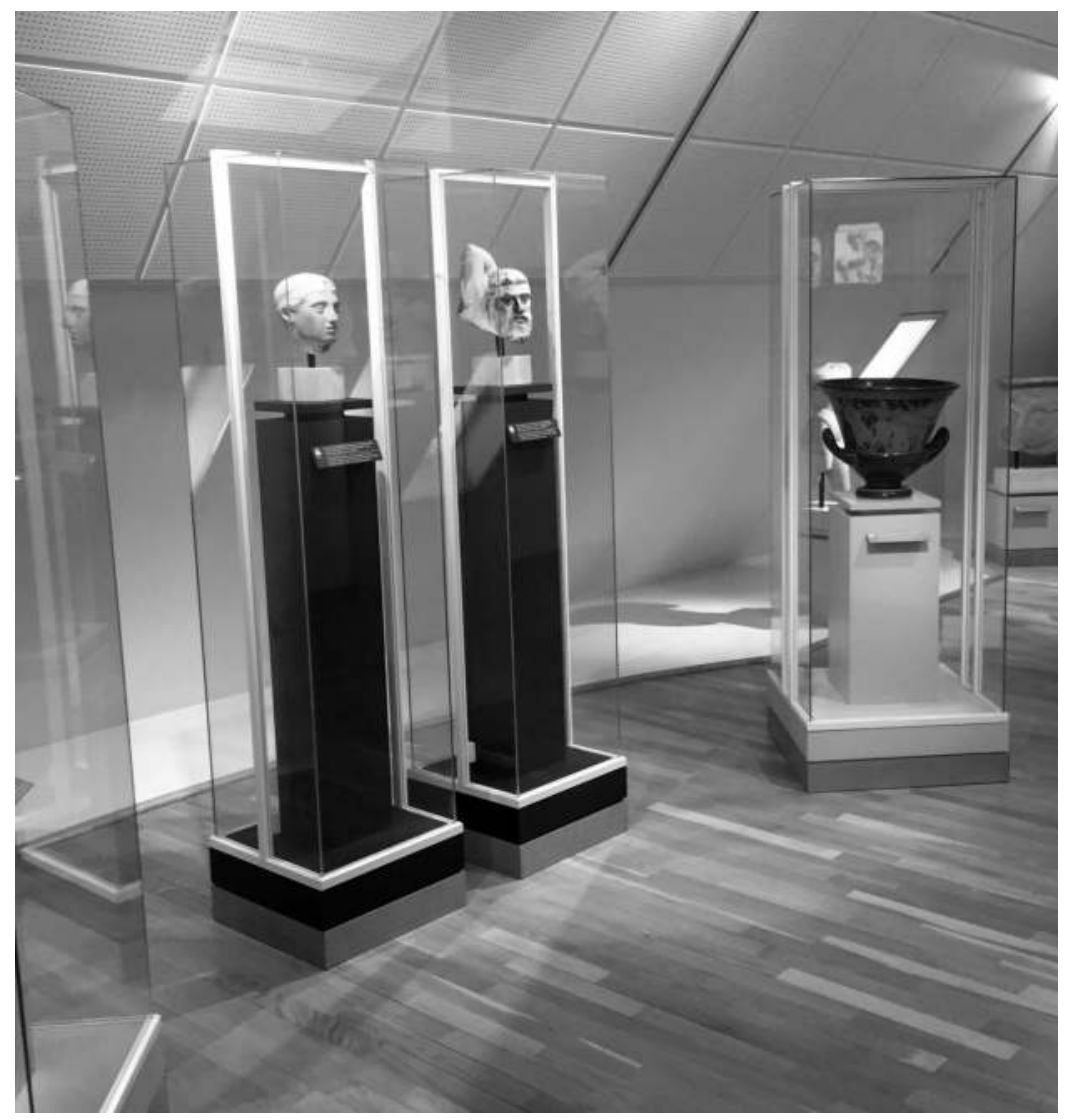

Figure 1.2 Danish material claims to classical antiquity: The display of two marble heads, originally belonging to a metope from the Parthenon, on display in the National Museum in Copenhagen

Source: Photo courtesy of Lærke Maria Andersen Funder 
Creating an imagined geography entails imbuing physical spaces with immaterial concepts: values, ideals and properties. These operations are what turn the Athenian Acropolis from a space to a place (Yalouri 2001). In characterising the effects of these operations, philosopher Jeff Malpas distinguishes between the concepts of space and place, stating that while space "tends towards the homogenous, the regular, and the uniform," place "is defined by relation to the notion of bound, limit or surface" and is "a locus of meaning, memory and identity" (Malpas 2014, 4; see also Malpas 2012; Berry 2009). The concept of place is defined both by its relation to other places and through the creation of new relations and new places that add temporality through those processes. This conceptualisation of place incorporates a diachronic and contextual idea of identity formation, showing how the human experience is played out within and across networks of places (Malpas 2014, 4, 11-12). The process of turning space into place is essentially discursive, but in the extended sense of the term, it involves material as well as immaterial elements. An archaeological excavation with its description, documentation and interpretation can be seen as a process of "place-making." Likewise, a museum exhibition transforms from a space to a place through the collection and organisation of the objects and information on display, very often referring to other places - and indeed helping to define these places further. School curricula are another example of textual and visual discourses in which place may be constituted through historical and cultural qualifications of geographical areas, which in turn are made meaningful in relation to the students' own cultural context. In this way the concept of imagined geography is applied as a perspective through which identity as connected to culture, heritage and place can be explored. In the following chapters we thus argue that the Danish discourse of classicism can be defined as an imagined geography through a series of cultural practices and constructed narratives that extend beyond the borders of the nation state and that construct a particular notion of European identity.

\section{Danish nationhood and European identities}

Current academic research into the nexus between culture, identity and heritage in a European context operates with a consensus that all three concepts must be understood in the plural - in contrast to the singular construction of European identity as construed on the sign at the entrance to the Acropolis (Delanty 2013; Macdonald 2013; Whitehead et al. 2015). The plurality of identities, cultures and heritages is a challenge especially to academic subjects with a normative, paradigmatic history that is embedded in large societal institutions such as curricula, museums or field practices such as archaeological excavations. It is also a challenge to a nation such as 
Denmark, which is one of the oldest monarchies in Europe. Historian Uffe Østergaard has defined the Danish nation state as "a rare situation of virtual identity between state, nation and society" (Østergaard 1992, 3), seemingly leaving little room for plurality. This is, however, a more recent phenomenon than is normally recognised in Denmark: "It is very hard to question what seems natural. This certainly applies to the sense of belonging to a nation, so totally taken for granted in modern times - particularly by the Danes" (Hall, Korsgaard and Pedersen 2015, 3). Danish nation-building and identity construction are traditionally situated in a local political, economic and social crisis of the nineteenth century. In this section, this process is discussed with a special focus on the meaning and role of classicism in the development of national identities, specifically focusing on the case of Denmark, while also pointing to key developments in other European countries.

Going back to the Renaissance, classical antiquity had been established as a paradigmatic part of European culture, constituting a cross-national dimension of classicism that could be defined as universal from this point onwards. In the centuries following the birth of humanism in fourteenth-century Italy, the power of the classical past as an ideal and as a source for construction of regional and local cultural identities was honed across Europe (Weiss 1969; Barkan 1999; Díaz-Andreu 2001, 430). Consequently, the cultural elites established classical heritage as valuable cultural capital in Europe before the establishment of the modern nation state. Europe's cultural and economic elite looked first to classical antiquity, but during the sixteenth century they increasingly appropriated their own local pasts for the construction of a historical foundation for their nations. The past in all its forms - literature, art and architecture - was recorded, collected, imitated and appropriated in order to take possession of its paradigmatic power of making identities (Miller 2017). Thereby, a dual dimension of local versus universal pasts was embedded into the reception and appropriation of the past.

Despite the competition from local pasts in Scandinavia, formulated through Gothicism (Norris 2016; Rix 2011), classical antiquity became central in imagining a European ideal in Renaissance Denmark. An important part of the early studies of Gothicism was in fact to trace connections between classical and Swedish history, establishing the Goths as the culture from which the Greeks originated (Siapkas 2017, 62-63). This link was as mentioned, established already in the Icelandic Edda. Through Christianity, Latin arrived in Denmark with the Catholic Church, and among the learned clerks the interest in classical texts grew (Horster and Funder 2017). After the Reformation, the Danish elites participated in the European patterns of building up royal collections, founding universities and, later, art academies. With the establishment of absolute monarchy in 1660 over a composite state consisting of the kingdoms of Denmark and Norway, the duchies of 


\section{Classical heritage and European identities}

Schleswig and Holstein, the North Atlantic territories of Greenland, Iceland and the Faroe Islands, and adding colonies in the West Indies, West Africa and India, the Danish monarchy belonged to one of the largest European multinational states (Østergaard 1992, 3, 2004, 25-29). Classicism during this period, up to around 1800, was embedded in aristocratic and royal symbolic language that appropriated especially the Roman imperial language of power through royal architectural settings such as Frederiksborg Castle (1602-1625) and equestrian statues of Danish kings (Figure 1.3).

During the eighteenth century, the Enlightenment and a process of institutionalisation had placed classical heritage in a central position in the Danish cultural landscape. Through the application of a classical formal language in education and in art and architecture, an imagined geography was established that connected Denmark to a broader European community of nobilities and intellectuals. Denmark partook in both the formulation and the diffusion of classicism on a European scale, whereby individuals and their European connections played a key role in integrating core ideas of classicism both in Denmark and in Europe (Kryger 1991). The Danish

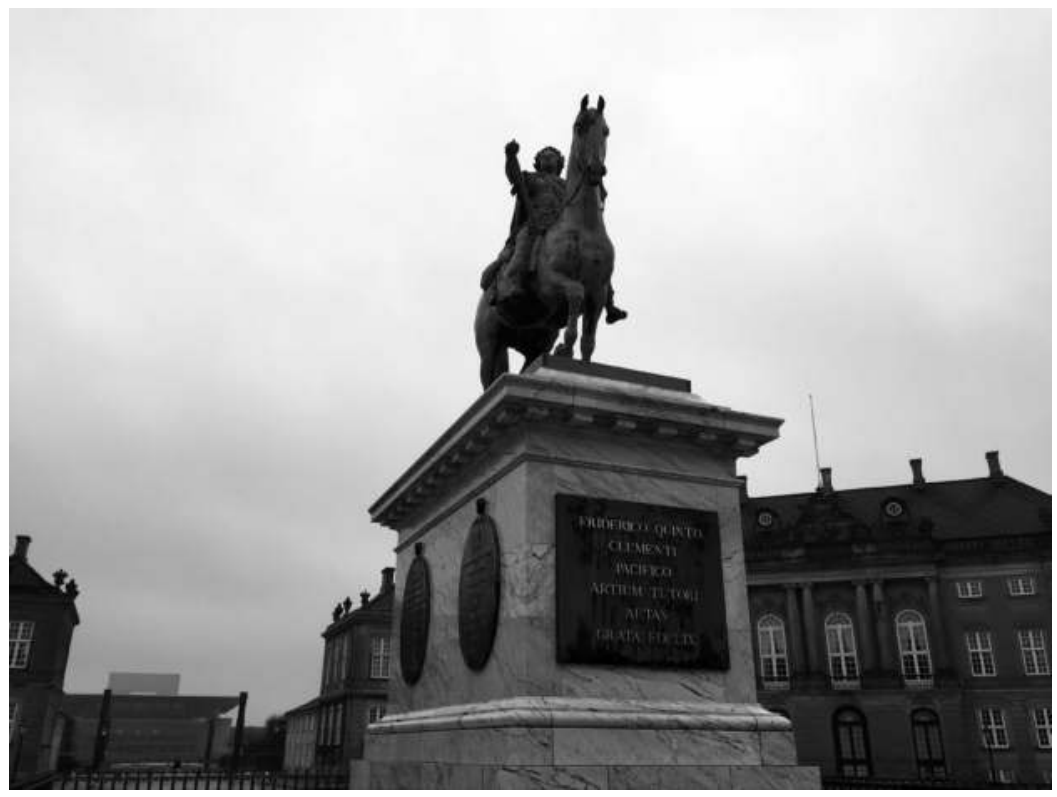

Figure 1.3 Equestrian statue of Frederik V, Amalienborg, Copenhagen, by Jacques Saly (1754-1768)

Source: Photo courtesy of Troels Myrup Kristensen 
sculptor Johannes Wiedewelt (1731-1802) was a close friend of the influential art historian Johann Joachim Winckelmann (1717-1768) and translated his work into Danish (Nielsen and Rathje 2010). Wiedewelt was instrumental in the foundation of the Royal Art Academy in Copenhagen in 1754. Neoclassicism became very strong in Denmark, not least through the work of the sculptor Bertel Thorvaldsen (1770-1844), who lived and worked for most of his life in Rome. Thorvaldsen's collection and works were donated to the Danish state and became the first public museum in Denmark when it opened in 1848 (Melander 1993). Heirs to this tradition, the two Danish architects Christian (1803-1883) and Theophilius Hansen (1813-1891) were among the prime European agents in developing neoclassicism as a common European architectural language in Athens, Vienna and Copenhagen (Jørgensen and Porphyrios 1987; Panourgiá 2004). The Hansen brothers illustrate well how the international networks of the elite were essential in the diffusion of classicism as a strong symbolic language of an imagined geography across Europe.

Margarita Díaz-Andreu has identified neoclassicism as the root of the civic nationalism that defined Europe up until the 1870s (Díaz-Andreu 2001, 431). In civic nationalism, the key concepts were citizenship, territory and equal rights for all citizens based on civilisation through universal education in classical cultures. Civilisation is here opposed to ethnic nationalism, which focused on the local national culture (Jørgensen 2005, 97-98; Daugbjerg 2011, 11). The civic nationalism developing in Denmark was patriotic, true to the King, and rooted in a small nobility and an elite educational system. Claus Møller Jørgensen divides the classical heritage of European civilisation into a Latin/French aesthetic tradition and a neohumanistic Greek/German tradition (Jørgensen 2005). The aesthetic tradition was strong in the visual arts, as seen above, whereas the neohumanistic tradition became essential in the educational system.

The broader European conception of civilisation as building on classical heritage was completely embedded in Danish education and culture by the turn of the eighteenth century. Classical education was considered essential, and the Greek and Latin languages were the most important subjects in school. Even the teaching of Danish was carried out on the basis of classical literature, as Danish literature was considered less sophisticated than the classical and authors could only proceed to a higher standard if they were learning style and rhetoric from Greek and Roman writers (Jørgensen 2005, 105). As in other European countries, learning and education were in the hands of the Church and were mainly limited to the literate classes until the late eighteenth century (cf. Adams 2015 on England). Public schools first became widespread in Europe from the late eighteenth century, and in Denmark compulsory learning was implemented with the 
first school law covering all children in 1814 . This came simultaneously with a widespread recognition of local languages. Danish became a school subject in 1775, and language emerged as a key element in the definition of Danish identity during the nineteenth century.

For the Danish development, the connection to Germany was absolutely paramount. As Suzanne Marchand has pointed out, philhellenism in Germany was a process of aligning the ideals from ancient Greece with aristocratic models and, during the nineteenth century, institutionalising them in research institutions, schools and museums - all essential educational institutions (Marchand 1996, xvii-xix). Danish educational systems were modelled on the German during this period of institutionalisation, and a key concept in this development was Bildung, translated in Danish into dannelse. This concept still plays a fundamental role in discourses on education in Denmark, now using the extended form of Allgemeinbildung (almendannelse in Danish). Many authors struggle to translate these concepts into English. In this book we have chosen to keep the German Bildung and translate Allgemeinbildung into general education.

The political and social changes of the late eighteenth and early nineteenth centuries in Europe affected profoundly the stable and prospering Danish monarchy. In order to benefit economically, Denmark tried to remain neutral in the conflict between France and the rest of Europe after the French revolution. However, Denmark eventually used its military to secure free trade and thus provoked an attack from Great Britain in 1801 and 1807 , resulting in the loss of the navy, a state bankruptcy in 1813 , and the loss of Norway in 1814 (Hansen 2001, 115-119; Østergaard 2004, 29; Daugbjerg 2011, 11). In postrevolutionary Europe, the diminished Danish state turned to a Danish or Nordic past to define and develop an imagined national community. The systematic collection of archaeological artefacts from Danish soil began with the foundation of the Antiquities Commission in 1807 (Jensen 1992). Classical antiquities were also collected from this time onwards, as will be discussed in chapter 3 . It is worth emphasising that these local and classical collections were not exclusive, but existed in the royal collections side by side. It is through disciplinary developments during the nineteenth century that archaeologies came to be defined as different. This was as much a political as a scientific process (Whitehead 2009).

The turn towards ethnic nationalism, with a stronger focus on the local past, accelerated in the 1830s and 1840s, implying a strong romantic and organic relationship between antiquities, nationalism and identity (Daugbjerg 2011, 11-12). It was expressed by the Danish archaeologist and later director of the National Museum Jens Jacob Asmussen Worsaae in 1840/41 when he defined the power of the past to "awaken the sensibility for our magnificent antiquities and the deference of the fatherland and the honour of our nationality that is inseparable from them" (cited from Daugbjerg 2011, 12). In 
this sense, heritage has been instrumental in defining Danish identity since the early nineteenth century. As has been pointed out, Denmark was the first European country to draw on excavations and exhibitions of national antiquities as part of the project of constructing a national identity, as opposed to classical and Near Eastern antiquities (Díaz-Andreu 2001, 432-434; Daugbjerg 2011, 11). This may be one of the reasons why classicism has received very little attention in studies of nationalism and identity in nineteenthcentury Denmark (Bang 2005). Indeed, a wide-ranging study on identity published in 1991-1992 contains practically no mention of classical heritage in nineteenth-century development (Feldbæk 1991-1992).

A significant aspect of the development of Danish nationalism during the nineteenth century is the role of the peasants. Uffe Østergaard has demonstrated how they during the nineteenth century developed into a strong political entity in Denmark. A growing non-elite nationalism among the farmers was one of the foundations for the movement of the priest, author, philosopher and poet Nikolaj Frederik Severin Grundtvig (1783-1872), whose concepts of the people and the national as culturally defined were heavily inspired by Herder's ideas about the relationship between people, nation and culture (Daugbjerg 2011; Larsen and Larsen 2011, 251-254). Grundtvig was an essential figure in the reform of the Church - not only through his revivalist thinking and the more than 1,500 psalms that are one of his most prolific legacies, but also through the educational system (Østergaard 1992, 6-11; Rerup 1993; Haue 2003, 52-53; Hall, Korsgaard and Petersen 2015). Through the Folkehøjskole (Folk High School), an independent educational institution that was essential in providing an education for ordinary people, Grundtvig democratised education. The schools were key elements in the growing self-esteem of Danish farmers, who came to constitute an alternative elite (Østergaard 1992, 13-14).

The political engagement of the peasants was at first local and regional, but in the 1870s they joined in the united "Left" party (Det Forenede Venstre). By then, the Danish state had been completely transformed: first through the peaceful revolution of $1848 / 49$, leading to the change to a constitutional regime with a democratically elected parliament, and second through a bloody war with Prussia over the two German duchies, in which Denmark's defeat in 1864 reduced the country to a very small and humiliated state. With the defeat, Danish nationalism was boosted through the famous saying "Outward losses must be made up by inward gains" (cited from Østergaard 2004, 32). In this new environment, the peasants were not the only constituency to promote a strong national sentiment. A new class of industrial entrepreneurs took over the values and cultural symbols of the declining old nobility. One essential figure was J. C. Jacobsen (1811-1887), who founded the Carlsberg breweries. He was active in politics, and he invested in national culture through the total rebuilding of the burnt-out Frederiksborg Castle, which was transformed into 
a Museum of National History. His most influential activity, however, was the establishment of the Carlsberg Foundation as proprietor of the breweries. Jacobsen secured the connection to science by donating the foundation to the Royal Danish Academy of Sciences and Letters in 1876 (Glamann 1976). It has since then supported academic research, not least within classical archaeology. Beginning with the excavation of Lindos, the Carlsberg Foundation has been fundamental to Danish archaeological projects in the Mediterranean. Unlike the German excavations, which were sponsored by the government, the Danish projects demonstrate a particularly close relationship between public and private donors in Danish archaeology. The Carlsberg Foundation's investment in the Rhodes excavation, together with earlier expeditions to Greenland and the construction of the Ny Carlsberg Glyptotek, were part of the larger nation-building remit of the Carlsberg Foundation. Crudely stated, the mission of the foundation - which has continued to have close ties with Danish academia - amounts to what could be called a public-private partnership with the overarching aim of modernising Denmark and making proper cultured Europeans of its citizens (cf. chapter 2).

Marchand identifies art and archaeology as essential materials in the process of Hellenisation in Germany; in fact, she argues that what made Greek culture the choice among others when Germany was searching for past cultures as sources of renewal was the materialisation of the aesthetic in large marble sculptures (Marchand 1996, xix, 5). Collections of ancient art constituted an essential part of the cultural expression of identity building in the rising nation states in Europe. The British Museum in London and the Louvre in Paris were material manifestations of imperial ambition, and through the layout of their collections, classical art was constructed in a chronological framework as the birth of European culture. Marble sculpture had not been very dominant in the Danish royal collections, which had focused on Greek painted pottery. This changed following the collecting activities of J. C. Jacobsen's son, Carl Jacobsen (1842-1914) who amassed one of the largest sculpture collections in Northern Europe in the late nineteenth century founding the Ny Carlsberg Glyptotek, thereby placing Denmark, a small country, in the same league as the large European states through its classical collections (cf. chapter 3).

\section{Three case studies}

The following chapters develop the lines of enquiry in three different arenas: education, collecting and archaeological fieldwork. Chapter 2 focuses on the subject entitled Classical Studies (in Danish Oldtidskundskab), which has been compulsory in Danish upper secondary schools (gymnasieskolen) since 1903 and which remains one of the most important settings through which Danes encounter classical heritage. In the nineteenth century, the educational 
system experienced increased pressure from outside to widen the subjects taught by the addition of natural science and mathematics. This development forced politicians to consider the role of individual subjects in teaching either as part of the general education in the tradition of Bildung or as concrete skills to the productive benefit of society. In this crossfire, classical languages became a contested area. The chapter analyses the development of the educational system in the nineteenth century that led to the invention of this new subject, named after the German Altertumswissenschaft. When we focus on the discourses preceding the invention of Classical Studies and those appearing during the twentieth century, when the subject was threatened with closure, it becomes clear that the cultural heritage particularly of ancient Greek culture was perceived as essential in understanding Danish culture in a European context. In this respect, the subject creates an imagined geography linking Denmark to Europe, which is particularly influential given its wide reach to all students in upper secondary school.

In chapter 3, we turn to the public museum. The role of the museum as a site for the education of the people has been present since the inception of public museums in Denmark, when Christian Jürgensen Thomsen gave private tours around the Nordic Museum, which became the National Museum of Denmark in 1892. The classical collection in the National Museum was originally part of the royal collection and was expanded by Christian VIII. The chapter presents an analysis of the exhibitions of the National Museum and the Ny Carlsberg Glyptotek at the turn of the twenty-first century. It demonstrates how the representations of classical antiquity in the permanent displays are rendered as Danish national and international cultural identities, and how these displays situate Denmark in a European cultural landscape. The chapter focuses on the permanent displays because the exhibition format is grounded in objects from the permanent collection and thus represents a historicity of interpretation of this body of objects within a given institution. While the displays express the preferences of the institution at the given time and context within which the displays were created (Gade 2006, 22), they also reflect the ethos and traditions of the institution. Therefore, the history of the classical collections, and how they entwine not only classicism but also the museum institution in a Danish conceptualisation of belonging to a European culture, will figure as a background against which the current displays can be understood.

Whereas the preceding two chapters focus on discourses of classicism within the borders of the nation state of Denmark itself, chapter 4 turns to Bodrum (ancient Halikarnassos, now located in modern Turkey) as one of the most important sites abroad where Danish archaeologists have been active in recovering classical heritage from the ground for more than 50 years. The importance of Bodrum in broader discourses of classicism is 
twofold. Firstly, the city is the birthplace of the Greek historian Herodotus (c. 480-c. 425 BC), who takes a central place in the curriculum of Oldtidskundskab. Secondly, it is home to the Mausoleum, which was built in 353-330 BC for the burial of Maussollos, the Persian satrap of Karia, and his sister-wife Artemisia II and considered to be one of the seven wonders of the ancient world. Danish fieldwork in Bodrum began formally in 1966 with Kristian Jeppesen's excavations at the site of the Mausoleum. Later Danish work has expanded to focus on other parts of the city and its surrounding archaeological landscapes. In 2016, the Danish fieldwork in Bodrum celebrated its 50th anniversary, which makes it the longest-ever Danish archaeological project in the Mediterranean. Students and professors from all three Danish universities that offer teaching in classical archaeology have participated in this fieldwork. Bodrum is thus a significant site of Danish classical heritage production, and one which, in turn, plays an important role in a variety of identity constructions. In light of Bodrum's location in modern Turkey, which has a long and complex relationship with Europe in its own right, this is a place where the Danish imagined geography of classical heritage is continuously confronted with the geopolitics of the present.

Together, these three case studies emphasise different but interconnected ways in which classical heritages are being put to use in order to construct Denmark's imagined geography and its own distinctive national identity within Europe. They show how Danish public and private investment in classical antiquity builds on a desire to connect with an ideal of the European nation state that can be traced back to the eighteenth century, if not earlier. classical heritages have thus historically been central components in the national imagination in Denmark. Partly for this reason, they have also been contested, and they continue to be challenged in new ways in the present by political, economic and cultural shifts.

\section{Notes}

1 Original capitalisation. Athens was awarded the European Heritage Label in 2014 based on a report by experts (https://ec.europa.eu/programmes/creative-europe/ actions/heritage-label_en). The report explains Athens' European significance in more detail: "The heart of Ancient Athens comprises nearly 100 monuments of European significance, such as the Acropolis hill, the Pnyx hill, and the Kerameikos cemetery. They make up a rich historical landscape where events fundamental to the formation of essential aspects of European culture and identity took place, from the development of classical art and theatre, to democracy, equal rights, and science. These monuments witnessed the birth and upbringing of key figures in European history whose intellectual achievements made an indelible mark on the definition of European common values as expressed in a variety of areas ranging from political and legal thought (Pericles), art and architecture (Phidias), 
literature and drama (Aeschylus, Sophocles, Euripides), medicine and science (Hippocrates), historical writing and the construction [of] memory (Herodotus, Thucydides), just to name a few." Athens also served as the first European Capital of Culture in 1985. Currently no Danish site has been awarded the European Heritage Label.

2 Text and video of Macron's speech at the Pnyx on 7 September 2017 are available online: www.elysee.fr/declarations/article/discours-du-president-de-la-republiqueemmanuel-macron-a-la-pnyx-athenes-le-jeudi-7-septembre-201/ (last visited 3 May 2018).

3 A case in point is www.Danmarkshistorien.dk, a widely used web resource on Danish history that does not include any discussion of classical heritage. 